\title{
Agnieszka Drzazga* \\ Kreatywny biznes na przykładzie firmy funkcjonującej w branży materiałów izolacyjnych
}

Streszczenie: W rozdziale poruszono problematykę kreatywności i innowacyjności w praktyce gospodarczej na przykładzie małej firmy zlokalizowanej w Łodzi i funkcjonującej na rynku materiałów izolacyjnych. Niniejsze opracowanie ma charakter teoretyczno-empiryczny i składa się z kilku części. Pierwsza z nich stanowi wprowadzenie do tematyki przedsiębiorczości, kreatywności i innowacyjności przedsiębiorstw. Następnie przedstawiono definicje kreatywności i innowacyjności oraz zaprezentowano ich znaczenie dla powodzenia współczesnych przedsiębiorstw. W kolejnej dokonano charakterystyki łódzkiego przedsiębiorstwa funkcjonującego w branży materiałów izolacyjnych oraz przedstawiono wyniki wywiadu, przeprowadzonego z właścicielem badanej firmy, w postaci studium przypadku. W ostatniej części przedstawiono wnioski z przeprowadzonych badań oraz podsumowanie. Przeprowadzone badanie $w$ formie wywiadu $\mathrm{z}$ właścicielem firmy funkcjonującej $\mathrm{w}$ branży materiałów izolacyjnych, pozwoliło na zaprezentowanie tego przedsiębiorstwa w niniejszym rozdziale jako przykładu organizacji uczącej się, kreatywnej i innowacyjnej.

Słowa kluczowe: kreatywność, innowacyjność, organizacja ucząca się, branża materiałów izolacyjnych.

\section{Wstęp}

Słowo przedsiębiorczość posiada wiele różnych definicji. Jedną z nich wskazują Piotr Kaczmarek-Kurczak oraz Magdalena Kaczmarek, określając przedsiębiorczość jako rodzaj twórczego działania. Porównując prowadzenie działalności gospodarczej z pracą najemną - inicjatywa, wybór kierunków działań oraz całe ryzyko spoczywa na barkach samego przedsiębiorcy. Należy oczywiście zaznaczyć, że poszczególne firmy różnią się między sobą poziomem innowacyjności i tak, jak poszczególni

* Wydział Zarządzania, Uniwersytet Łódzki. 
ludzie - są mniej lub bardziej twórcze. Za przedsiębiorstwa najbardziej twórcze uznać należy takie podmioty gospodarcze, które swój byt i rozwój zawdzięczają przewadze konkurencyjnej, osiągniętej dzięki oferowaniu nowych rozwiązań, produktów lub usług [Kaczmarek-Kurczak, Kaczmarek, 2014: 2].

W związku z powyższym, ważnymi elementami wpływającymi na uzyskanie przewagi konkurencyjnej są kreatywność, rozumiana jako zdolność do tworzenia nowych i korzystnych rozwiązań oraz innowacyjność oznaczająca umiejętność wprowadzania i zastosowania tych rozwiązań w realiach gospodarczych. Kluczowe znaczenie w przedsiębiorstwie mają również inne umiejętności oraz zasoby wiedzy, będące składowymi kompetencji, m.in. zdolność do kreatywnego myślenia zespołu pracowniczego, co jest niezbędnym warunkiem tworzenia innowacji. Innowacyjność przedsiębiorstwa zależna jest zatem od sposobu traktowania kreatywności przez właściciela, menedżera oraz pracowników [Krawczyk-Sokołowska, 2018: 55].

Przedsiębiorstwo innowacyjne jest organizacją uczącą się, aktywnie uczestniczącą $\mathrm{w}$ procesie pozyskiwania, kreowania i przekazywania wiedzy, przede wszystkim za pośrednictwem procesu wymiany doświadczeń i umiejętności w zakresie prowadzonej działalności wytwórczej i usługowej [Sopińska, 2008: 66].

Kreatywność i innowacyjność wiążą się ze zmianami w organizacji, nowymi pomysłami, które są siłą napędową biznesu oraz podstawą sukcesu każdego przedsiębiorstwa [Skowron-Grabowska, 2013: 13].

Celem rozdziału jest zaprezentowanie przykładu innowacyjnego przedsiębiorstwa funkcjonującego w regionie łódzkim, z którego właścicielem, na potrzeby niniejszego opracowania, został przeprowadzony wywiad.

Wyniki wywiadu zostały przedstawione w formie studium przypadku w kolejnej części niniejszego opracowania.

\section{Kreatywność i innowacyjność w biznesie}

Kreatywność i szeroko pojmowana działalność innowacyjna mieszczą się w obszarze zainteresowania nauki oraz praktyki gospodarczej. Niepewność i zmienność otoczenia organizacji wymusza realizowanie niestandardowych działań. W dzisiejszych czasach rozwój przedsiębiorstwa zależy w głównej mierze od kreatywności i innowacyjności. Kreatywność jest bezpośrednio związana $\mathrm{z}$ tworzeniem pomysłu, natomiast innowacyjność oznacza zdolność jego zastosowania - przedstawia użyteczność tego pomysłu i źródło korzyści dla interesariuszy. W związku 
z tym, istnieje potrzeba wspierania kreatywności i innowacyjności, gdyż są one podstawowym stymulatorem nowoczesności przedsiębiorstw.

Rozwój nauki i techniki kreuje nowe potrzeby i oczekiwania ludzi, co wymusza na dzisiejszych przedsiębiorstwach konieczność szybkiego reagowania na rosnące wymagania klientów i dopasowania swojej oferty do ich potrzeb [Korkosz-Gębska, 2014: 956].

Kreatywność, we współczesnym świecie, uznawana jest za jedną z najważniejszych cech kapitału ludzkiego, wpływającą na wdrażanie innowacji i będącą podstawą procesu innowacyjnego. Cechę tę można zdefiniować jako sposób myślenia, polegający na wyszukiwaniu szczególnych zależności pomiędzy elementami i łączeniu ich w niespotykany sposób [Matusiak, 2005: 152]. Należy ją utożsamiać ze zdolnością człowieka do generowania nowych koncepcji, idei lub skojarzeń i wiązania ich z istniejącymi już pomysłami oraz koncepcjami [Skrzypek, 2014: 177]. Kreatywność więc jest zdolnością twórczego myślenia, łączenia różnych pomysłów w unikatowy sposób, przyjmowania różnych założeń lub postrzegania określonej rzeczy z nowej perspektywy [Bieniok, 2014: 55].

Kreatywność w organizacji określana jest zwykle jako kreowanie nowych oraz użytecznych pomysłów. Dzięki zdolności do tworzenia czegoś nowego i użytecznego, firmy osiągają wymierne efekty m.in. takie jak wzrost wartości firmy. Z punktu widzenia przedsiębiorstwa kreatywność postrzegana jest jako wynik - efekt twórczego działania, w postaci stworzonych produktów, usług, procesów itd., które są nowe i użyteczne [Brzeziński, Leszczyńska, 2009: 22].

Uwarunkowania kreatywności w organizacji można przedstawić za pomocą formuły $4 \mathrm{P}$ :

1. People (ludzie),

2. Process (proces),

3. Press (presja),

4. Product (produkt).

Tworzenie sprzyjających warunków kreatywności wymaga wdrażania odpowiednich działań w przedsiębiorstwie, które wpływają na rozwój kreatywności zespołu pracowniczego a do których m.in. zaliczyć można budowanie systemu kompetencyjnego i motywacyjnego [Nęcka, 2001: 19-20]. Rozwijanie kreatywnego potencjału zespołu pracowniczego w organizacji jest fundamentalnym elementem procesu poszukiwania i wdrażania innowacyjnych rozwiązań.

Kreatywność jest jedną z głównych cech określających charakterystykę przedsiębiorcy, a jej poziom jest istotnym wyznacznikiem jego innowacyjności [Karpacz, 2011: 8]. Proces innowacyjny polega na łączeniu nowych idei i wiedzy w nową wartość. Kreatywność pozwala 
wyzwolić tworzenie nowych pomysłów i stanowi źródło innowacji, polegającej na wdrażaniu najlepszych pomysłów w życie. Innowacyjność zatem jest naturalnym wynikiem kreatywności, która bezpośrednio związana jest $\mathrm{z}$ generowaniem pomysłu, a innowacyjność oznacza umiejętność jego zastosowania. Proces innowacji oznacza możliwość i niezbędność zastosowania kreatywności do realizacji wszystkich faz procesu innowacji, do których należą:

1) faza kreacji,

2) faza rozwoju,

3) faza wdrożenia,

4) faza dyfuzji.

Zastosowanie kreatywności w przedsiębiorstwie pozwala w znaczący sposób poprawić efektywność generowanych innowacji. Stopień innowacyjności firmy zależy m.in. od sposobu traktowania innowacji przez poszczególne osoby w przedsiębiorstwie: od właściciela po pracowników. Ważnym aspektem przedsiębiorstwa innowacyjnego jest stosowanie systemu motywacyjnego, który wzmocni przedsiębiorczość kierownictwa i kreatywność zespołu pracowniczego [Romanowska, 2015: 6].

Kluczowymi atutami przedsiębiorstwa innowacyjnego są zdolność uczenia się oraz prognozowania i dokonywania zmian. Firma innowacyjna jest organizacją uczącą się, która aktywnie uczestniczy w procesie pozyskiwania, kreowania i przekazywania wiedzy, w głównej mierze poprzez proces wymiany doświadczeń i umiejętności w zakresie prowadzonej działalności wytwórczej i usługowej [Sopińska, 2008: 66].

Kreatywność i innowacje są dwiema nakładającymi się na siebie strukturami pomiędzy dwoma fazami procesu kreowania: fazą generowania idei oraz fazą wdrażania rozwiązań. Kreatywność i proces twórczego myślenia w praktyce gospodarczej oznaczają zdolność do tworzenia nowych i korzystnych rozwiązań (pomysłów, wytworów), natomiast innowacyjność to umiejętność wprowadzania i zastosowania tych rozwiązań w realiach gospodarczych. Innowacyjność stwarza szanse dla współczesnych przedsiębiorstw na sukces rynkowy. Ważne przy tym jest jednak to, by innowacyjność $\mathrm{w}$ organizacji pozostawała $\mathrm{w}$ silnym związku z kreatywnością osób funkcjonujących w przedsiębiorstwie. Kreatywność ta ściśle wiąże się z zarządzaniem wiedzą $\mathrm{w}$ organizacji, w tym z zarządzaniem wiedzą zatrudnionych osób. Umiejętne nią zarządzanie stwarza warunki do rozwijania kreatywności wszystkich pracowników, przynosi organizacjom wymierne korzyści w obszarze wzrostu skuteczności decyzji, lojalności, zaufania, kultury, jakości, wiedzy i doświadczeń, a finalnie wpływa na innowacyjność przedsiębiorstwa i wzrost jego konkurencyjności. 


\section{Studium przypadku lódzkiej firmy funkcjonującej w branży materiałów izolacyjnych}

Na potrzeby niniejszego rozdziału, przeprowadzono wywiad z długoletnim przedsiębiorcą i zarazem właścicielem firmy funkcjonującej w branży materiałów izolacyjnych. Przedsiębiorstwo powstało w roku 1989 i jest zlokalizowane w Łodzi. Firma zajmuje się produkcją i sprzedażą materiałów izolacyjnych, stosowanych w budownictwie do ociepleń budynków mieszkalnych i przemysłowych, instalacji oraz izolacji termicznych. Oferuje ona także usługi w zakresie: izolacji zbiorników i rur, ociepleń dachów, ociepleń ścian i izolacji komór wypornościowych w jachtach.

Jak twierdzi właściciel, od początku funkcjonowania działalności, firma stworzyła wiele rozwiązań, które odnotowały wielki sukces na polskim rynku, np. wypełnienie wolnych przestrzeni w murach czy izolacja termiczna rur na miejscu budowy. W ofercie badanej firmy znajduje się szeroka gama produktów ociepleniowych. Wszystkie posiadają niezbędne certyfikaty.

Produkty badanej firmy w zasadniczej części bazują na piance poliuretanowej (PU), produkowanej w tym przedsiębiorstwie z komponentów pozyskiwanych w Polsce. Materiał ten jest najkorzystniejszym spośród dotychczas użytkowanych, jak np. styropian czy wełna mineralna. Właściciel firmy oferuje klientom swoją 30-letnią praktykę w dziedzinie produktów izolacyjnych i wysoką jakość materiałów. Przedsiębiorstwo produkując materiał izolacyjny w postaci pianki poliuretanowej oferuje dużą wartość dodaną. Tradycyjne materiały izolacyjne są często stosowane w sposób niewłaściwy, czego skutkiem jest konieczność remontów i napraw, a to z kolei wiąże się ze znacznymi kosztami i problemami realizacyjnymi oraz wydłużeniem czasu inwestycji. Natomiast wybierając piankę poliuretanową, klienci unikają problemu zastosowania jej w sposób niewłaściwy. Pianka PU z uwagi na swoje własności eliminuje wiele błędów wykonawczych i projektowych oraz daje komfort w eksploatacji na długie dziesięciolecia.

Wiodący pracownicy firmy oraz właściciel biorą udział w różnego rodzaju szkoleniach oraz konferencjach poświęconych problematyce termomodernizacji budynków oraz stosowania nowoczesnych materiałów ociepleniowych i izolacyjnych $\mathrm{w}$ instalacjach budynków mieszkalnych i przemysłowych, a także instalacjach ciepłowniczych. Ponadto właściciel firmy udziela się naukowo prowadząc wykłady, dotyczące nowoczesnych technik izolacyjnych, na Politechnice Łódzkiej, a także w Branżowej Izbie Gospodarki Mieszkaniowej oraz poprzez współpracę w zakresie 
termomodernizacji budynków mieszkalnych ze wspólnotami mieszkaniowymi. Wyżej wymienione aktywności kadry i zespołu produkcyjnego, zdaniem przedsiębiorcy, mają znaczący wpływ na wysoką jakość i nowoczesność realizowanych projektów.

Właściciel przedsiębiorstwa ukończył studia wyższe na Wydziale Budownictwa, Architektury i Inżynierii Środowiska Politechniki Łódzkiej. Jak wynika z przeprowadzonego wywiadu, właściciel badanej firmy jest osobą posiadającą orientację przedsiębiorczą:

- jest proaktywny (potrafi znaleźć miejsce dla siebie i swojej firmy w branży materiałów izolacyjnych na krajowym rynku specjalistycznych materiałów budowlanych oraz wykorzystać istniejące szanse),

- jest innowacyjny (stosuje nowoczesne metody produkcji i oferuje niekonwencjonalne systemy ociepleń),

- jest skłonny, w ograniczonym zakresie, bezpiecznym dla stabilności firmy, do podejmowania ryzyka w ramach prowadzonej działalności.

Istotnym elementem dla innowacyjności firmy, według właściciela przedsiębiorstwa, poza jego osobistym profilem kompetencyjnym, są także profile kompetencyjne członków kierownictwa firmy, a także pozostałych pracowników. Syn właściciela, który również zajmuje się prowadzeniem biznesu, ukończył studia na Wydziale Mechanicznym Politechniki Łódzkiej, a zatrudnione do produkcji osoby ukończyły średnie szkoły zawodowe, technika lub licea głównie o profilu mechanicznym i budowlanym. $Z$ uwagi na posiadane doświadczenie i wieloletnią praktykę zawodową $\mathrm{w}$ branży materiałów izolacyjnych w budownictwie $i$ instalacjach przemysłowych można $z$ powodzeniem stwierdzić, że zarówno właściciel badanej firmy, jak i jego syn posiadają wysokie kompetencje branżowe/techniczne, a także menedżerskie wynikające $\mathrm{z}$ doświadczenia związanego $\mathrm{z}$ wieloletnim prowadzeniem przedsiębiorstwa.

W perspektywie czasu, według badanej firmy, najważniejszym co wpłynęło na osiągnięcie sukcesu były następujące czynniki: wysokie kwalifikacje kadry kierowniczej i wiedza merytoryczna związana z prowadzoną działalnością, reakcja w odpowiednim czasie na zapotrzebowanie rynku, umiejętności myślenia kreatywnego zatrudnionych pracowników, które miały swój niekwestionowany wpływ na stworzenie przez firmę innowacyjnych rozwiązań, a także takie elementy jak: wysoka jakość i terminowość realizacji.

Badane przedsiębiorstwo realizuje strategię rozwoju poprzez poszerzanie asortymentu materiałów ociepleniowych, wdrażanie nowych roz- 
wiązań, a także nowych technologii produkcji. Firma przeznacza na badania i rozwój 15\% wypracowanego zysku, głównie na badania jakości produktu, certyfikaty, patenty itp.

Aktualnie konkurencja badanej firmy jest znacząca - najpoważniejsza to duże przedsiębiorstwa np. ATLAS, który specjalizuje się m.in. w systemach ociepleń ścian zewnętrznych budynków czy firma Compact Izolacje, która tak jak badana firma funkcjonuje od 1989 roku oraz zajmuje się realizacją robót izolacyjnych przy wykorzystaniu m.in. pianki poliuretanowej.

Umiejętne zarządzanie finansami, zdolność do kreatywnego myślenia oraz innowacyjność produkowanych dóbr, według właściciela w istotny sposób wpływają na dobrą kondycję firmy. Przedsiębiorstwo unika finansowania działalności ze środków zewnętrznych w postaci kredytu. Według oceny właściciela o sukcesie firmy i jej pozycji na rynku świadczą uzyskiwane przez przedsiębiorstwo zyski. Szczegółów na temat aktualnie osiąganych zysków właściciel nie ujawnił, zasłaniając się tajemnicą biznesową. Jedyne wyniki finansowe firmy, które zostały ujawnione przez właściciela to przychód (tj. łączna wartość sprzedaży dóbr, towarów i usług netto - bez VAT) w 2014 roku, który wynosił 500000 zł - według uzyskanej od przedsiębiorcy informacji trend w tym zakresie ma tendencję wzrostową.

Właściciel badanej firmy jest entuzjastą nowoczesnych rozwiązań technicznych w zakresie materiałów izolacyjnych i pasjonatem nowych technologii ich wytwarzania. Posiada szeroką i udokumentowaną wiedzę $z$ tego zakresu. Firma zawdzięcza swoje powodzenie pasji jej właściciela, który oprócz dochodów z jej prowadzenia czerpie przyjemność $\mathrm{z}$ wdrażania swoich nowych pomysłów i innowacyjnych rozwiązań technicznych.

Obecnie w firmie zatrudnione są 3 osoby będące członkami rodziny i 7 osób nienależących do rodziny - wszystkich pracowników obowiązuje jeden system wynagradzania. Zarówno pracownicy, jak i kadra zarządzająca wynagradzani są $\mathrm{w}$ oparciu o regulamin płacowy firmy, zgodny z kodeksem pracy, oraz stosowany system motywacyjny przewidujący prowizje i premie w sytuacji zrealizowania planów produkcyjnych, a także stworzony dla pracowników zgłaszających najciekawsze pomysły innowacyjne mogące wpłynąć na rozwój firmy.

Badane przedsiębiorstwo jest posiadaczem wielu patentów na wynalazki. Produkty firmy zostały także docenione przez różne instytucje, które przyznały przedsiębiorstwu wiele prestiżowych nagród, jak np.:

- Nagroda Specjalna Prezydenta Miasta Łodzi przyznana w konkursie na najlepsze łódzkie wyroby, 
- Nagroda Wojewody Łódzkiego przyznana za innowacyjność produktową w postaci produkcji materiałów izolacyjnych z pianki poliuretanowej.

\section{Wnioski z badań}

Przedstawione studium przypadku firmy funkcjonującej w branży materiałów izolacyjnych pokazuje, że wiedza, kreatywność, innowacyjność, doświadczenie i determinacja przedsiębiorcy oraz zatrudnionych pracowników pozwalają właścicielowi badanego przedsiębiorstwa prowadzić z sukcesem do dnia dzisiejszego nowoczesną firmę, potrzebną na rynku materiałów budowalnych i jednocześnie osiągać osobisty sukces oraz satysfakcję z prowadzonej działalności. Umożliwianie pracownikom uczestnictwa $\mathrm{w}$ innowacyjnych konferencjach czy zachęcanie do zgłaszania kreatywnych pomysłów, są istotnymi elementami organizacji uczącej się, a także w znaczący sposób wpływają na rozwój poszczególnych pracowników oraz całego przedsiębiorstwa. Sukces badanej firmy jest rezultatem nie tylko wiedzy i doświadczenia, ale i pasji z jaką przedsiębiorca prowadzi swój biznes. Mimo że badana firma jest przedsiębiorstwem zaliczanym do sektora MŚP, to jej obecność na rynku i perspektywa dalszego funkcjonowania są niekwestionowane. W aktualnie trwającym boomie budowlanym ma ona przed sobą w dalszym ciągu dobre perspektywy prowadzenia nowoczesnej i innowacyjnej działalności gospodarczej.

\section{Zakończenie}

Zdolność firmy do tworzenia innowacji i ich wdrażania, stanowi współcześnie jeden z najważniejszych czynników budujących przewagę konkurencyjną. Innowacyjność przedsiębiorstwa umożliwia zaspokajanie dotychczas istniejących lub kreowanie nowych potrzeb klientów. Generowanie i wdrażanie innowacji przez przedsiębiorstwo, wymaga jednak umiejętności twórczego myślenia oraz kreatywności przedsiębiorców, a także zatrudnionych $\mathrm{w}$ firmie menedżerów i pracowników. Mimo iż zaszczepienie kreatywności u wszystkich pracowników jest zadaniem trudnym, odpowiednio zarządzana firma, o ile rozumie istotę i znaczenie tworzenia innowacyjnych rozwiązań, jest w stanie odpowiednio ukierunkować swoich pracowników i zmotywować ich do 
twórczego myślenia i tworzenia nowatorskich pomysłów, wychodzących naprzeciw rosnącym oczekiwaniom klientów. Przykładem takiego przedsiębiorstwa jest opisana firma funkcjonująca w branży materiałów izolacyjnych.

\section{BIBLIOGRAFIA}

Bieniok H. (2014), Kreatywność jako źródto nowoczesności i rozwoju przedsiębiorstw, „Organizacja i Zarządzanie”, nr 73, s. 47-58.

Brzeziński M., Leszczyńska A. (2009), Kreatywność a dynamika organizacji, „Organizacja i Zarządzanie", nr 1(5), s. 21-29.

Kaczmarek-Kurczak P., Kaczmarek K. (2014), Kreatywność i przedsiębiorczość, [w:] Spoteczne Forum Przedsiębiorczości, https://www.kozminski.edu.pl/fileadmin/wspolne _elementy/Jednostki/sfop/Artykuly_expertow/22_Kreatywnosc_i_przedsiebiorczosc.pdf (dostęp: 15.05.2019).

Karpacz J. (2011), Kreatywność przedsiębiorców jako determinanta poszukiwania szans, „Przegląd Organizacji”, nr 1, s. 8-11.

Korkosz-Gębska J. (2014), Kreatywność i innowacje w zarządzaniu nowoczesnym przedsiębiorstwem, [w:] Innowacje w Zarządzaniu i Inżynierii Produkcji, Oficyna Wydawnicza Polskiego Towarzystwa Zarządzania Produkcją, Warszawa, s. 956-966.

Krawczyk-Sokołowska I. (2018), Kreatywność stymulatorem postaw proinnowacyjnych w przedsiębiorstwie, Oficyna Wydawnicza SGH, Warszawa.

Matusiak K.B. (2005), Innowacje i transfer technologii. Stownik pojęć, PARP, Warszawa.

Nęcka E. (2001), Psychologia twórczości, Gdańskie Wydawnictwo Psychologiczne, Gdańsk.

Romanowska M. (2015), Innowacyjne przedsiębiorstwo w nieinnowacyjnej gospodarce, „Przegląd Organizacji”, nr 8, s. 4-8.

Skowron-Grabowska B. (2013), Procesy innowacyjno-konkurencyjne $w$ strategiach przedsiębiorstw, „Przegląd Organizacji”, nr 6, s. 13-18.

Skrzypek E. (2014), Kreatywność a zarządzanie wiedza, „Zeszyty Naukowe Małopolskiej Wyższej Szkoły w Ekonomicznej w Tarnowie", nr 1(24), s. 175-188.

Sopińska A. (2008), Wiedza jako strategiczny zasób przedsiębiorstwa. Analiza i pomiar kapitalu intelektualnego, Oficyna Wydawnicza SGH, Warszawa.

\section{CREATIVE BUSINESS ON THE EXAMPLE OF A COMPANY OPERATING IN THE INSULATION MATERIALS INDUSTRY}

\section{SUMMARY}

The chapter addresses the issues of creativity and innovation in business practice on the example of a small company located in Lodz and operating on the market of insulating materials. This study is of a theoretical and empirical nature and 
consists of several parts. The first one is an introduction to the subject of entrepreneurship, creativity and innovativeness of enterprises. Chapter One presents the definitions of creativity and innovation and their significance for the success of modern enterprises. Chapter Two features the Lodz based enterprise operating in the insulation materials industry and presents the results of the interview conducted with the owner of the researched company in the form of a case study. The last part presents conclusions from the conducted research and a summary. The conducted survey in the form of an interview with a company operating in the field of insulation materials allowed for presentation of this company in this chapter as an example of a learning, creative and innovative organization.

Keywords: creativity, innovation, learning organization, insulation industry. 